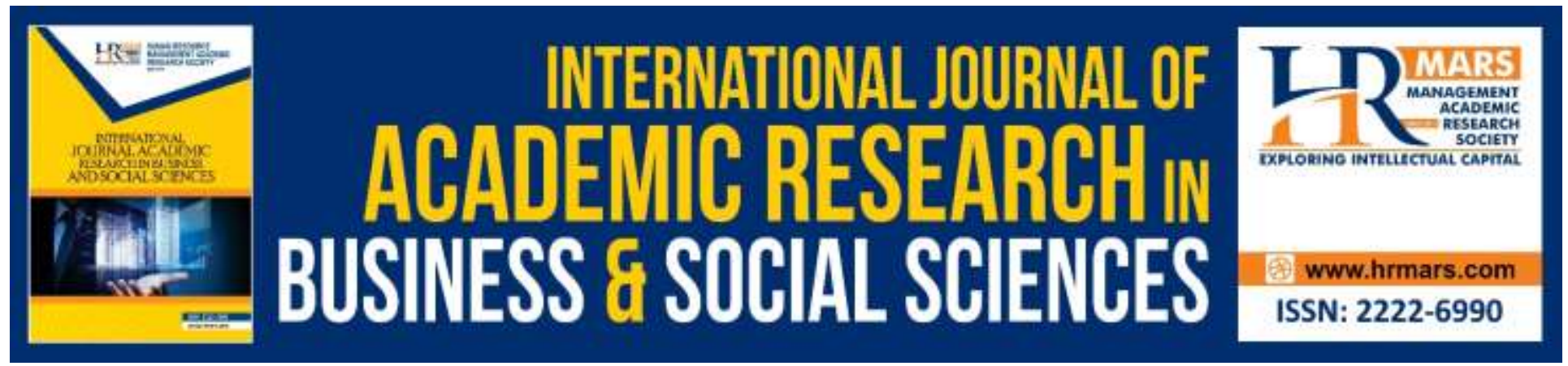

\title{
The Characteristic and Issues in Liberal Islam in Malaysia
}

\section{Fatin Najwa Binti Ridzuan, Wan Khairul Aiman Wan Mokhtar, Asma Afifah Rashid Eusoff Amiruddin, Ahmad Safwan Jamaludin}

To Link this Article: http://dx.doi.org/10.6007/IJARBSS/v9-i11/6577

DOI: 10.6007/IJARBSS/v9-i11/6577

Received: 09 October 2019, Revised: 27 October 2019, Accepted: 03 November 2019

Published Online: 26 November 2019

In-Text Citation: (Ridzuan, Mokhtar, Amiruddin \& Jamaludin , 2019)

To Cite this Article: Ridzuan, F. N. B., Mokhtar, W. K. A. W., Amiruddin, A. A. R. E., Jamaludin, A. S. (2019). The Characteristic and Issues in Liberal Islam in Malaysia. International Journal of Academic Research in Business and Social Sciences, 9(11), 572-578.

Copyright: (C) 2019 The Author(s)

Published by Human Resource Management Academic Research Society (www.hrmars.com) This article is published under the Creative Commons Attribution (CC BY 4.0) license. Anyone may reproduce, distribute, translate and create derivative works of this article (for both commercial and non-commercial purposes), subject to full attribution to the original publication and authors. The full terms of this license may be seen at: http://creativecommons.org/licences/by/4.0/legalcode

Vol. 9, No. 11, 2019, Pg. 572 - 578

Full Terms \& Conditions of access and use can be found at http://hrmars.com/index.php/pages/detail/publication-ethics 


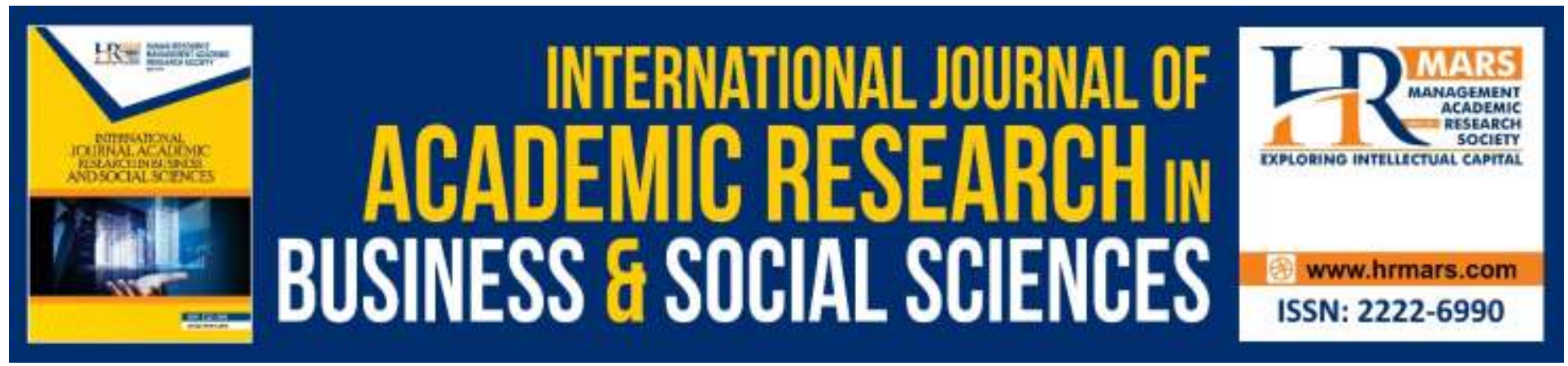

\title{
The Characteristic and Issues in Liberal Islam in Malaysia
}

\author{
Fatin Najwa Binti Ridzuan, Wan Khairul Aiman Wan Mokhtar, \\ Asma Afifah Rashid \\ Eusoff Amiruddin, Ahmad Safwan Jamaludin \\ Universiti Sultan Zainal Abidin (UniSZA), Gong Badak Campus, 21300, Kuala Nerus, Terengganu, \\ Malaysia
}

\begin{abstract}
This article is intended to discuss about the issue of liberal Islam in Malaysia. Liberal Islam is a religion that contradicts the true religion of Islam. This widespread liberation of liberal Islam is extremely dangerous as it is clearly against the Quran and al-Hadith. In addition, the beliefs brought by these followers are also incompatible with the true teachings of the Islamic religion and Ahlus Sunnah wal Jamaah (ASWJ). Followers of liberal Islam are more emphasizing the law based on common sense rather than referring to al-Quran and al-Hadith. The question arise in this situation is what is the threat brought by the followers of liberal Islam in Malaysia? How is the development of liberal Islam in Malaysia? To answer this question, this article has three objectives. Firstly, this article was created to identify the concept of liberal Islam. Secondly, to identify the characteristics of liberal Islam. Thirdly, to identify the issues in the Islamic society in Malaysia that are related to liberal Islam This qualitative research uses content analysis to analyze all the data that has been collected. Through this approach, the findings of the study are liberal Islam is a dangerous threat to the Muslim community in Malaysia. In addition, this liberal Islamic understanding can influence the thinking of the Muslim community in Malaysia as the people in Malaysia are still not open about this concept.
\end{abstract}

Keywords: Liberal Islam, Concept, Characteristics, Issue, Malaysia

\section{Introduction}

Looking at the current globalization and 21st century, more and more threats arise to undermine the sacred and harmonious religion of Islam. In line with the modernization period, there are many associations and organizations that use the name of Islam but have brought in opposition to the Quran and al-Hadith. Liberal Islam is one of those who try to absorb in every Muslim and 
are trying to get into their own Islamic society. This understanding is very dangerous as it seeks to encourage weak Muslims in religious affiliation to follow.

The question is, what is the threat posed by the followers of liberal Islam in Malaysia? And how is the development of liberal Islam in Malaysia? This is why the study was conducted.

The discussion on the flow of liberal Islam is very important to highlight. Therefore, it is very important for every Muslim to have the knowledge related to this liberal Islam. Therefore, this study is conducted on three objectives, namely, first, to learn about the Islamic liberal concept, the second, to identify the features of liberal Islam and the third, to identify issues related to liberal Islam in Malaysia.

In general, the discussion in this study is divided into three main categories. The main category is the discussion of the concept of liberal Islam. The second category is the characteristic of Islamic liberal ideology while the third category is about issues in Islamic society in Malaysia in relation to liberal Islam.

\section{Research Methodology}

A good study is to produce the right findings. Findings form study that been made requires from research methodology. A right methodology that been applied for the study comes to the good and comprehensive study (Mokhtar, 2017).

To achieve the objectives of this study, qualitative method has been used. The focus of this study is based on a descriptive study observation research. In addition, library research is also used as one of the methods for data collection. Form the collected data, the data is analyzed using the content analysis method. After the data collection, the conclusion was made. (Mokhtar, 2017).

\section{Findings and Research Discussion}

In order to discuss about liberal Islam in Malaysia, this study is divided into three parts. The first part of the concept of liberal Islam, the second part, on the features of liberal Islam and the third ideology of Islam is about issues related to liberal Islam in Malaysia.

\section{Liberal Islamic Concept}

According to the Chamber Dictionary, Liberal words are as follows: 1 . Tilt to freedom and democratic governance, 2. Be free or open-minded, open-minded (unconditional to other flows) In this context, the term liberal Islam is meant by a stream of values that emphasize change and freedom which surpasses what has already existed in Islam (Tatar, 2015). This flow requires more openness and freedom than what is already in Islamic law (Abdullah, 2007). Although liberal Islam does not have a specific definition but it can be concluded as an effort to bring about the modernization of Western countries that is well-known and adopted as a factor in the development of knowledge (Rahim \& Ali, 2018). By using such a purpose to advance the minds of Muslims, the followers of this religion are calling for a more open and progressive Islamic understanding (Ibrahim, Majid, Awang, Najib \& Othman, 2013). As such, the followers of this liberal Islam began to fight for change in Islam by reinterpreting the Quran, al-hadith, syariah, religious authority and ijtihad using the mere intellectual basis (Zarif \& Abdullah, 2015; Georgia 
\& Alexandra, 2018). Liberal Islamic thought is a form of ideology that puts the principle of freedom and openness in every aspect of life so that it can transcend the boundaries that have been established by Islamic law and law that have existed in Islam itself (Dagang, Masroom, Baharuddin \& Mustari, 2015).

According to Dagang et al. (2015), this liberal Islamic movement is derived from the liberalism philosophy that developed in Western countries such as economic liberalism, cultural liberalism, political liberalism and religious liberalism. The followers of this liberal Islam are very dangerous because they do not show themselves as people who reject Islam but hide behind some things like slogans reviewing the religion, the Quran, the Islamic Sharia and figh law. The followers of this understanding are trying to reject what has been taught in Islam since long ago as something old and old (Dagang et al., 2015; Zaini, 2018).

According to Shahran (2018), if it continues to mention and use the term liberal Islam, it would be easy to be a simple ticket to these followers to legalize their interpretation of religion. The followers of liberal Islamic beliefs believe that religion should be adapted to the current circulation despite having to reject the original Islamic religious laws. In addition, if there is a law that does not suit the age, modernity, human rights and global civilization, then the law should be changed according to the needs and suitability of their thinking or should be disposed of as well as their understanding (Tatar, 2015; Gitau, Kiragu, Kamau, 2018).

\section{Characteristics of Liberal Islam}

Among the features of liberal Islam include rejection of religious authority and follow the notion of freedom to fight in any religious-related problem by any individual. Relativism is a methodology adopted which means truth is something that is relatively and cannot be prosecuted by any party (Ibrahim et al., 2013). The followers of this liberal Islam have divided the revelation into two parts, namely the first, written revelation while the second chapter is an inexplicable revelation. The Quran is a written revelation and they say the Quran as a mere text while the unwritten revelation is also human reason. According to this understanding, the Quranic texts are restored by human reason based on the purpose, context and mood of the times. Thus, they conclude that the Quran is something that describes the religion and human intellect as adjusting according to the age-old circulation. They regard Islamic sciences such as proposals, interpretations of figh, hadiths and others as long and frozen in Islamic disciplines (Abdullah, 2007). Using this reason, the followers of this liberal Islamic understanding reopened the discussion on the matters he claimed to be the true opinion (Masroom \& Dagang, 2015.). In addition, among other characteristics about liberal Islam is secularism. The idea of secularism is clearly influenced by the idea of secularism, so that there is a view that Islam is the sole claim of worship. The thought of this follower's minds argued that Islamic law is no longer suitable for practice today while most of Islam should be removed from life (Masroom \& Dagang, 2015). This liberal thought that supports the doctrine to separate religious affairs from human life is further explained by the Selangor Islamic Religious Department (JAIS) (2011) and even they believe and believe that freedom in action is a fundamental matter for every human being that cannot be 
tampered with. They even claim and adhere to the principle of "no compulsion in religion" which leads to the sole right of freedom of action as the Quran (Dagang et al, 2013).

Another feature of the liberal Islamist thought is the rejection of shariah, freedom of interpreting Islamic texts, no indictment of truth, promoting western values and supporting liberal democracy (Ismail, 2009).

\section{Issues Related To Liberal Islam in Malaysia}

According to Ibrahim et al. (2013), the followers of liberal Islam have a variety of beliefs and thoughts that form the basis of their struggle. Among them are followers of this belief fully supporting religious pluralism. Religious pluralism refers to the diversity of religions that exist among human beings as worship to the one god. In other words, this suggests that religious pluralism which refers to Islam is not the only true religion. Among the issues of religious pluralism that took place in Malaysia was on December 25, 2012, Lim Guan Eng had made extreme applications when asked for the Federal Government of Malaysia to officially authorize the word of Allah to be adopted by Christianity (Fadzir, 2013).

Furthermore, followers of liberal Islam also support gender equality. Among the well-known movements in fighting for the equality between men and women is the feminist movement. This movement normally requires that shariah laws be likened to men and women (Mazlan Ibrahim et.al, 2013). Among the issues of gender equality raised by this feminism movement is the rejection of polygamy which they follow will oppress women (Jamaluddin, 2015). In addition, closing aurah by the use of the lid is the way of use for the Arabs (Abdullah, 2007).

Likewise, this liberal Islamist follower also defends human rights that is clearly against the Islamic law of defending Lesbian, Gay, Bisexual and Transgender (LGBT). The followers are of the view that there is no reason to prevent such things as they think God has made all men equal, either men or women (Ismail, 2009). In Malaysia, there has been a backdrop to the inverse culture that we can see today, the inverted society is no longer ashamed to accentuate themselves as different from ordinary.

\section{Conclusion}

Based on discussion in this research, liberal Islam is an ideology that uses Islamic words to hide from the main intention of dividing Muslims in the world and in Malaysia in particular. Hence, liberal Islam is the thing that needs to be abandoned.

The flow of thought that speaks of religion by reason of misleading and confusing in argument is capable of giving great danger to Muslims with issues that are struggled so that it is considered the true teachings of Islam because of the sources they take from the al-Quran and the al-Hadith. Therefore, every Muslim needs to have knowledge of this liberal Islam because when we have knowledge about it, we will easily fend off all the evil elements that can disrupt and threaten this sacred religion. 


\section{Acknowledgement}

This paper is founded on the research project of the Fundamental Research Grant Scheme FRGS/1/2018/SSI03/UNISZA/02/2 (Project No: RR279). Special appreciation is owed to Ministry of Higher Education Malaysia (MOHE) and Universiti Sultan Zainal Abidin (UniSZA) for sponsoring and supporting this research.

\section{Corresponding Author}

Wan Khairul Aiman bin Wan Mokhtar (Ph.D), Senior Lecturer, Universiti Sultan Zainal Abidin (UniSZA), Kampus Gong Badak, 21300 Kuala Nerus.

Email:wk_aiman@yahoo.com / wkhairulaiman@unisza.edu.my

\section{References}

Abdullah, H. F. (2007). Membongkar Aliran Islam Liberal. Jahabersa: Johor Bahru.

Arifin, L. (2018). Waspada umpan istilah 'Islam liberal'. Retrieved from https://www.bharian.com.my/rencana/agama/2018/08/466911/waspada-umpanistilah-islam-liberal.

Dagang, W. I. W., Masroom, M. N., Baharuddin, A. S. \& Mustari, M. I. (2016). Cabaran Islam Liberal Kepada Umat Islam. Johor: Universiti Teknologi Malaysia.

Georgia, V., \& Alexandra, V. (2018). Promoting "aimer lire" through using Local Literature Material: A Proposed Program for Students of 5th and 6th Grades of Elementary School. Multilingual Academic Journal of Education and Social Sciences, 6(1), 52-65.

Gitau, G.G., Kiragu, D.N., Kamau, R. (2018). Effect of Heuristic Factors and Real Estate Investment in Embu County, Kenya, International Journal of Academic Research in Accounting, Finance and Management Sciences 8 (4): 30-38

Ibrahim, M., Majid, L. A., Awang, J., Kadir, M. N., \& Othman, M. F. (2013). Pengajian Islam Di IPT Malaysia Dalam Menanangi Islam Liberal. Selangor: Universiti Kebangsaan Malaysia.

Ismail. (2009). Cabaran Akidah Pemikiran Islam Liberal. Kuala Lumpur: Pejabat Mufti Wilayah Persekutuan.

Kamus Dewan. (1994). Kuala Lumpur: Dewan Bahasa dan Pustaka.

Masroom, M. N., \& Dagang, W. I. W. (2016). Cabaran Islam Liberal Kepada Umat Islam. Johor: Universiti Teknologi Malaysia.

Mokhtar, W. K. A. W. (2017). Concept Al-Hadīth Al-Mawḍū'iy as A Method of Collecting and Analyzing Research's Data. International Journal of Academic Research in Business and Social Sciences, 7(2), 536-542.

Rahim, S. A. \& Ali, M. S. (2018). Liberalisme Agama Di Malaysia: Satu Sorotan Literatur. Terengganu: Universiti Sultan Zainal Abidin.

Zaini, N. (2018). The Relationship between Multiple Intelligence on the Performance of Arts Stream Students in Linear and Non-Linear MUET Reading Component. International Journal of Academic Research in Progressive Education and Development, 7(4), 80-94.

Zarif, M. M. M., \& Abdullah, W. H. (2015). Kedudukan dan Peranan Hadis Dalam Terjemahan Liberalisme Terhadap Al-Quran Al-Karim. Dalam Khadher Ahmad, Faisal Ahmad Shah \& 
INTERNATIONAL JOURNAL OF ACADEMIC RESEARCH IN BUSINESS AND SOCIAL SCIENCES

Vol. 9, No. 11, November, 2019, E-ISSN: 2222-6990 @ 2019 HRMARS

Monika @ Munirah Abd Razzak (ed). Salah Faham Terhadap Sunnah Isu dan Penyelesaian. Kuala Lumpur: Universiti Malaya. 